\title{
Scanning electron microscopy of molluscum contagiosum
}

\author{
Microscopia eletrônica de varredura do molusco contagioso
}

\author{
Hiram Larangeira de Almeida $\mathrm{Jr}^{1}$ \\ Maiko Abel Schneider ${ }^{2}$ \\ Luis Antônio Suíta de Castró
}

\author{
Martha Oliveira Abuchaim² \\ Leandra Marques ${ }^{3}$
}

\begin{abstract}
Molluscum contagiosum is a disease caused by a poxvirus. It is more prevalent in children up to 5 years of age. There is a second peak of incidence in young adults. In order to examine its ultrastructure, three lesions were curetted without disruption, cut transversely with a scalpel, and routinely processed for scanning electron microscopy (SEM). The oval structure of molluscum contagiosum could be easily identified. In its core, there was a central umbilication and just below this depression, there was a keratinized tunnel. Under higher magnification, a proliferation similar to the epidermis was seen. Moreover, there were areas of cells disposed like a mosaic. Under higher magnification, rounded structures measuring 0.4 micron could be observed at the end of the keratinized tunnel and on the surface of the lesion.

Keywords: Microscopy, electron, scanning; Molluscum contagiosum; Molluscum contagiosum virus

Resumo: Molusco contagioso é uma dermatovirose causada por um poxvírus, sendo mais prevalente em crianças com até 5 anos de idade. Um segundo pico de incidência é encontrado em adultos jovens. Com o objetivo de demonstrar sua ultraestrutura três lesões foram curetadas sem rompê-las, cortadas transversalmente e processadas de rotina para microscopia eletrônica de varredura. A estrutura oval do Molusco contagioso pôde ser facilmente observada, no seu centro há uma umbilicação central e logo abaixo observa-se um túnel queratinizado. Com aumentos progressivos observam-se proliferações semelhantes à epiderme e áreas de células dispostas em mosaico. Com grandes aumentos estruturas arredondadas medindo 0,4 micron são vistas no final do túnel queratinizado e na superfície da lesão.

Palavras-chave: Microscopia eletrônica de varredura; Molusco contagioso; Vírus do molusco contagioso
\end{abstract}

\section{INTRODUCTION}

Molluscum contagiosum (MC) is a disease caused by a poxvirus of the Molluscipox virus genus and is characterized by umbilicated translucent papules of 1 to $3 \mathrm{~mm}$ in size. The disease is more prevalent in children up to 5 years of age. ${ }^{1}$ There is a second peak of incidence in young adults, mainly as a sexually transmitted disease. ${ }^{2}$ There have been a few reports of traumatic inoculation, such as that caused by tattoos. ${ }^{3}$
This study aimed to perform cross-sectional scanning electron microscopy (SEM) of MC.

Three MC lesions were curetted without disruption of their structure, cut transversely with a scalpel, and routinely processed for SEM.

\section{RESULTS}

Under lower magnification, the oval structure

Received on 18.05.2011.

Approved by the Advisory Board and accepted for publication on 27.06.2011.

* Work conducted as a course requirement - Federal University of Pelotas (UFPel) and Laboratório de Microscopia Eletrônica - Empresa Brasileira de Pesquisa Agropecuária (EMBRAPA-CPA-CT) - Pelotas (RS), Brazil.

Conflict of interest: None

Financial funding: None

Assistant Professor - Federal University of Pelotas (UFPel) - Pelotas (RS), Brazil.

Student of Medicine - Federal University of Pelotas (UFPel) - Pelotas (RS), Brazil

MD - Resident in Dermatology - Sanitary Dermatology - Porto Alegre (RS), Brazil

MSc - Responsible for Laboratório de Microscopia Eletrônica (Electron Microscopy Laboratory) - Empresa Brasileira de Pesquisa Agropecuária (Brazilian Enterprise for agricultural research- EMBRAPA-CPA-CT) - Pelotas (RS), Brazil. 
of MC could be easily identified. In its core, there was a central umbilication and just below this depression, there was a keratinized tunnel (Figure 1). Under higher magnification, it was possible to observe the epidermis and the stratum corneum; underneath the epidermis, there was a proliferation similar to the epidermis (Figure 2). Moreover, there were areas of cells disposed like a mosaic (Figure 3).

Examination of the keratinized tunnel revealed a similar aspect to that of normal skin surface, with scales arranged in a "roof-like" pattern (Figure 4). Under higher magnification, rounded viral structures measuring 0.4 micron could be observed at the end of

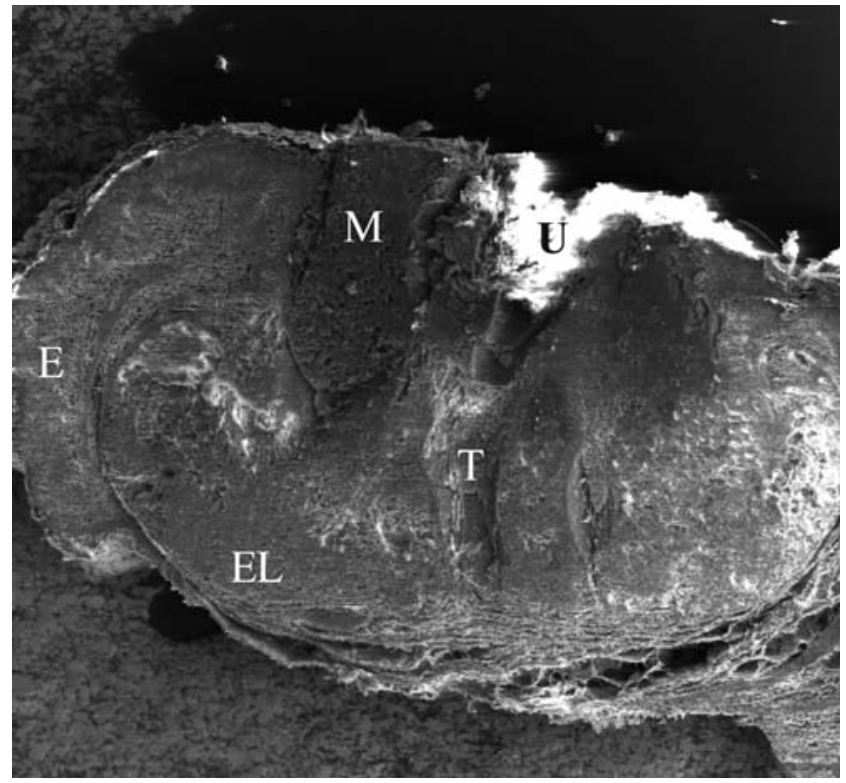

Figure 1: SEM under lower magnification ( $x 56)$ showing the entire structure of MC. E- epidermis; EL epidermis-like area;

U- central umbilication; T - keratinized tunnel; M- mosaic area the keratinized tunnel and on the surface of the lesion (Figures 5A and 5B).

\section{DISCUSSION}

These findings obtained through SEM revealed relevant information about the structure of MC. In the medical literature, there are two reports on the use of SEM and several others on transmission electron microscopy (TEM). ${ }^{4-9}$

Our ultrastructural findings are comparable to the ones obtained through optical microscopy, which show an epidermis-like layer encircling the proliferation caused by the virus (Figure 2 inset).

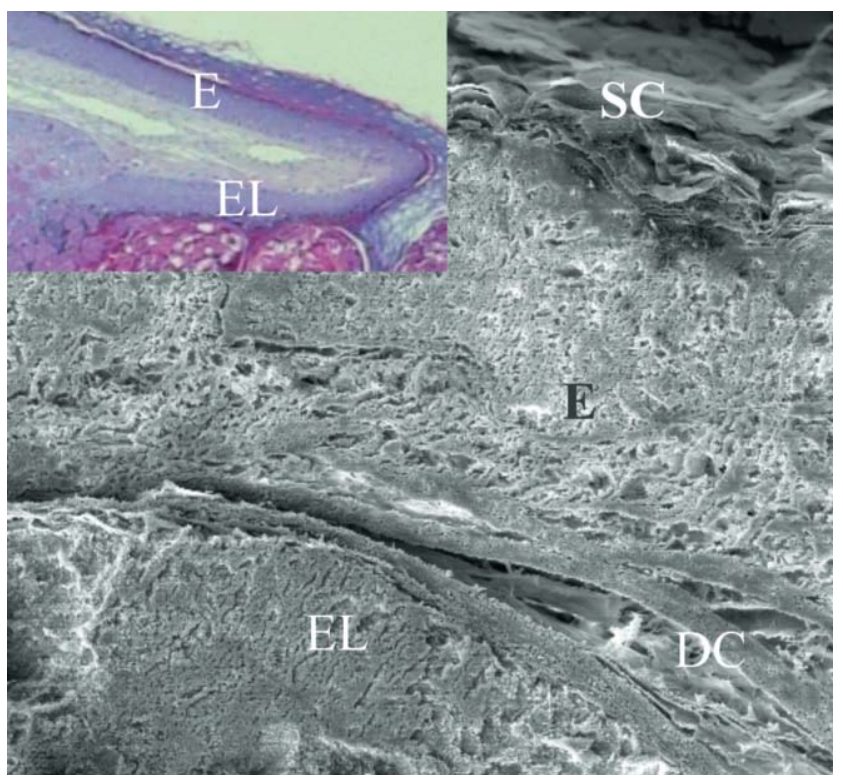

Figure 2: SEM (x 290) - SC - stratum corneum; E- epidermis ; ES epidermis-like; DC - dermal collagen. Note the comparison with light microscopy (inset), showing an epidermal-like layer underneath the epidermis
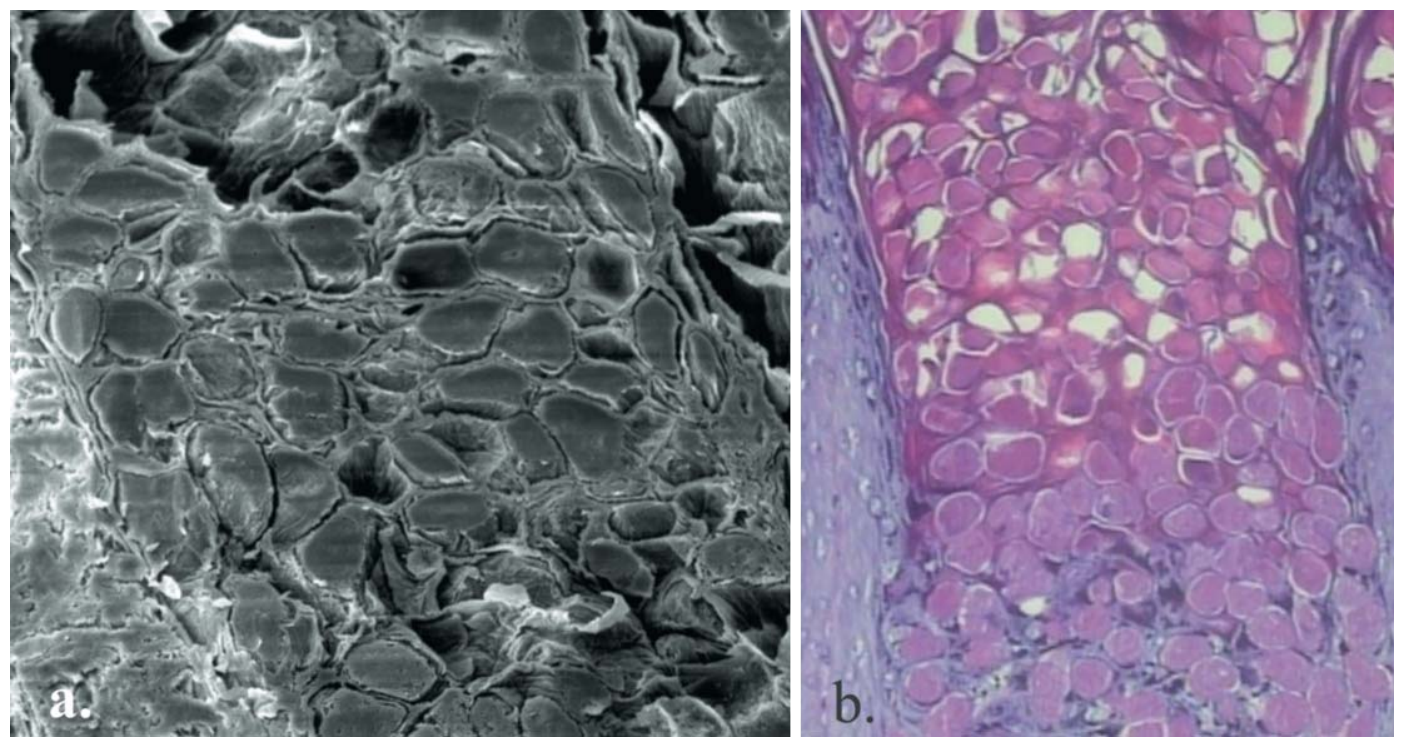

Figure 3: SEM (x 350) detail of the mosaic area (a) light microscopy with typical eosinophilic molluscum bodies (b) 


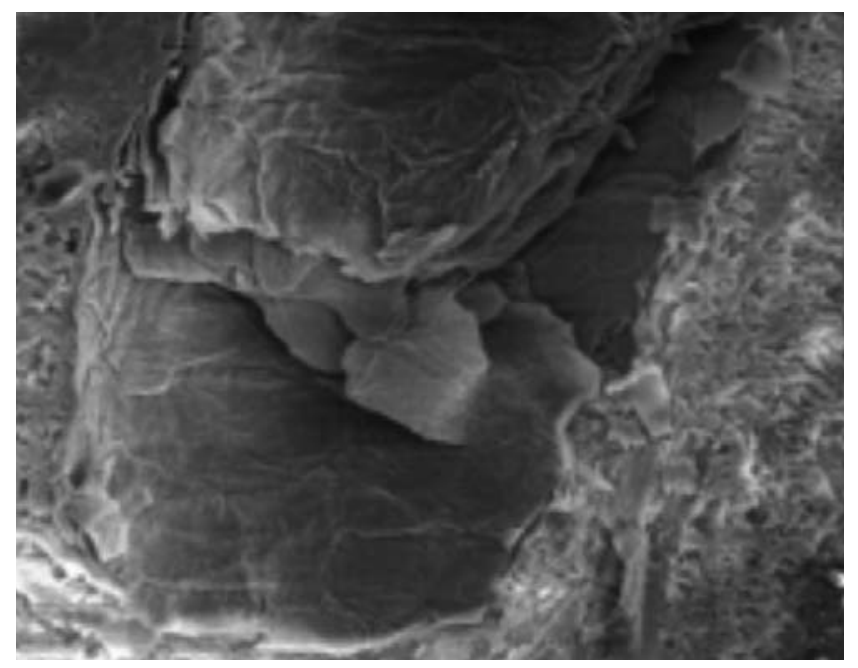

FigurE 4: SEM (x 350) detail of the keratinized tunnel
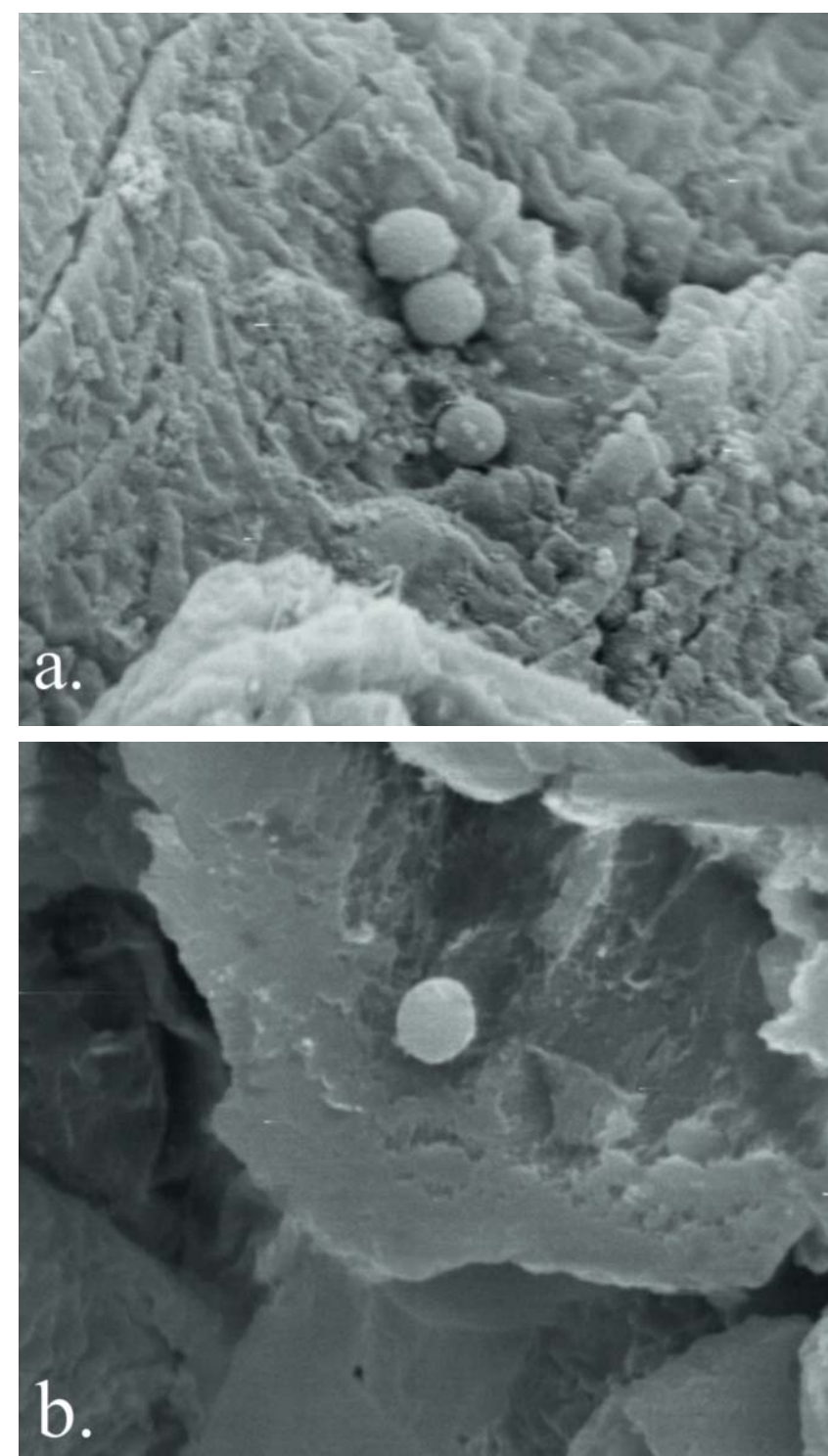

FIGURE 5: SEM (x 10.000) viral structures in the keratinized tunnel (a) and on the surface of the lesion (b)
The mosaic structure found in the cross-section corresponds to the so-called molluscum bodies seen on light microscopy, which consist of large cells with an eosinophilic granular cytoplasm and a small peripheral nucleus, considered pathognomonic of $\mathrm{MC}$ (Figure 3B). ${ }^{6}$ This structure is surrounded by the epidermis-like proliferation.

In a previous report about the use of SEM, these infected keratinocytes were described as a "viral colony sac". ${ }^{5}$ Reports on TEM showed large amounts of viral particles in the cytoplasm of these keratinocytes with lateral displacement of the cell nucleus. ${ }^{6}$ Other authors found nucleus lobulation secondary to compression caused by intracytoplasmatic viral proliferation. ${ }^{8}$

The viral morphology described previously through the use of SEM and TEM was spherical, ellipsoidal or brick-shaped. We only observed spherical structures in our findings. The reported size of the virus was also similar to the one we found. ${ }^{4}$

Interestingly, we found a keratinized tunnel just below the central umbilication and viral particles at the end of the tunnel and on the surface of the lesion, revealing its disseminated form. This tunnel could be reminiscent of hair follicle, suggesting that MC proliferation could start at the outer root sheath keratinocytes. These findings could also explain its dermal localization, in contrast to HPV infections, which are epidermal. $\square$ 


\section{REFERENCES}

1. Pannell RS, Fleming DM, Cross KW. The incidence of molluscum contagiosum, scabies and lichen planus. Epidemiol Infect. 2005;133:985-91.

2. Villa L, Varela JA, Otero L, Sánchez C, Junquera ML, Río JS, et al. Molluscum contagiosum: A 20-year study in a sexually transmitted infections unit. Sex Transm Dis. 2010;37:423-4.

3. Molina L, Romiti R. Molusco contagioso em tatuagem. An Bras Dermatol. 2011:86:352-4.

4. Mihara M. Three-dimensional ultrastructural study of molluscum contagiosum in the skin using scanning-electron microscopy. Br J Dermatol. 1991;125:557-60.

5. Shelley WB, Burmeister V. Demonstration of a unique viral structure: the molluscum viral colony sac. Br J Dermatol. 1986;115:557-62.

6. Jain S, Das DK, Malhotra V, Tatke M, Kumar N. Molluscum contagiosum. A case report with fine needle aspiration cytologic diagnosis and ultrastructural features. Acta Cytol. 2000;44:63-6.

7. Garcia J, Vicente V, Ochotorena MM, Hernandez-Gil A. Molluscum contagiosum. Estudio clinicopatológico y ultraestructural. Med Cut ILA. 1988;16:503-6.
8. Fonseca MEF, Machado RD, Liberto MIM, Marcolino G. Molluscum contagiosum serology and electron microscopy findings in twenty one patients. Rev Inst Med Trop São Paulo. 1987;29:86-9

9. Smith KJ, Skelton HG, Yeager J, James WD, Wagner KF. Molluscum contagiosum Ultrastructural evidence for its presence in skin adjacent to clinical lesions in patients infected with human immunodeficiency virus type 1. Arch Dermato 1992:128:223-7.

MAILING ADDRESS:

Hiram Larangeira de Almeida Jr

Faculdade de Medicina

Av. Duque de Caxias 250

96100-000 Pelotas RS.

E-mail: hiramalmeidajr@botmail.com

How to cite this article: Almeida Jr HL, Abuchaim MO, Schneider MA, Marques L, Castro LAS. Scanning electron microscopy of molluscum contagiosum. An Bras Dermatol. 2013;88(1):90-3. 